\title{
Sibling Position and Achievement: the Case of Sweden
}

\author{
BERTIL HOLMLUND
}

\section{Introduction}

Several psychological studies show a pronounced relationship between family size and the children's mental capacity, as revealed by various ability tests. From two-children families and upwards, the association is typically negative. Onlychildren appear to fall somewhat outside the general pattern and perform less well than those in two-children families. (See Walldén (1982) for a survey of sibling research in psychology and sociology.)

The relationship between mental capacity and number of siblings has been given several different interpretations. For example, the relationship may be due to parent differences that are correlated with family size. Essentially this argument is one of omitted variable bias. Another interpretation presumes a casual link between family size and mental development among children. High fertility families have, on average, less resources in terms of goods and time to devote to each of their children. A third interpretation focuses on the importance of birth order. Several studies indicate an inverse association between birth order and mental capacity. High fertility families will produce more children of high birth order and therefore more children with lower mental capacity; as a consequence, average child capacity may fall.

The economic approach to fertility of Becker and Lewis (1973) provides an optimization framework for understanding the relationship between quantity and »quality» of children. The basic idea is that household welfare depends on, inter alia, the number of children as well as various utility-affecting characteristics of the children, such as their intellectual and emotional development and ultimately their educational attainment and earnings power as adults.

Several significant policy issues are related to the nature of the tradeoff between the number and quality of children. One issue concerns the mechanisms whereby inequality across generations is transmitted and perpetuated. For example, if lowincome parents are more likely to have many children they will also be more likely to invest less in each of those children, since a large number will be associated with a higher shadow price of quality. Those who grew up with many siblings will therefore be equipped with less »endowment» from their parents and will probably receive less education and earnings as teenagers and adults. A »vicious circle» whereby intergenerational inequality is perpetuated is conceivable.

In this paper we explore the role of family size and other family background characteristics for Swedish children's educational achievements as adults. We start with a brief exposition of the quantity-quality fertility model and use this framework as a guide for specification of equations for parents' fertility demand as well as children's educational attainment. The empirical analysis is given on pages $102-106$ and a summarizing discussion concludes the paper.

\section{Analytical framework}

Consider a family acting as a single decision unit and attempting to maximize a well-behaved utility function

$$
\mathrm{U}=\mathrm{U}(\mathrm{N}, \mathrm{Q}, \mathrm{C})
$$


where $\mathrm{N}$ is the number of children, $\mathrm{Q}$ is the (average) quality per child and $\mathrm{C}$ is consumption of a composite commodity. Child quality represents a flow of services that provide direct utility to the household and is produced by each family by the use of time and market goods.

The utility function is maximized subject to a full income constraint

$$
\mathrm{I}=\mathrm{PNQ}+\mathrm{P}_{\mathrm{N}} \mathrm{N}+\mathrm{P}_{\mathrm{Q}} \mathrm{Q}+\mathrm{P}_{\mathrm{C}} \mathrm{C}
$$

where $\mathrm{I}$ is full income, $\mathrm{P}$ is the price per unit of quality, $\mathrm{P}_{\mathrm{C}}$ is the price of the composite commodity and $\mathrm{P}_{\mathrm{N}}$ and $\mathrm{P}_{\mathrm{Q}}$ are fixed prices related to quantity and quality. $\mathrm{P}_{\mathrm{N}}$ »includes the time, expenditure, discomfort, and risk spent in pregnancy and delivery, governmental child allowances (a negative cost), and all other psychic and monetary expenditures on children that are largely independent of quality». (Becker, 1981, 107.) $\mathrm{P}_{\mathrm{Q}}$ is associated with expenditures on children that are unrelated to the number of children because of joint consumption.

The first-order conditions resulting from utility maximization are

$$
\begin{aligned}
& \mathrm{U}_{\mathrm{N}}=\lambda\left(\mathrm{PQ}+\mathrm{P}_{\mathrm{N}}\right)=\lambda \pi_{\mathrm{N}} \\
& \mathrm{U}_{\mathrm{Q}}=\lambda\left(\mathrm{PN}+\mathrm{P}_{\mathrm{Q}}\right)=\lambda \pi_{\mathrm{Q}} \\
& \mathrm{U}_{\mathrm{C}}=\lambda \mathrm{P}_{\mathrm{C}}
\end{aligned}
$$

where $\lambda$ is the marginal utility of full income and $\pi_{\mathrm{N}}$ and $\pi_{\mathrm{Q}}$ are shadow prices of quantity and quality, respectively. An important point to note is that the shadow price of quantity depends on the level of quality and that the shadow price of quality depends on the level of quantity. This provides a basis for interaction effects as discussed in some detail by Becker (1981). For example, lower costs of contraceptives are likely to reduce the number of children, but may also have indirect effects through a lower shadow price of quality, leading to an increased demand for quality and a further decrease in the number of children.

Unlike conventional prices, these shadow prices are endogeneous and determined by the parameters of the problem, i.e., the price vector and full income. Eqs. (2) - (5) can be solved for the optimal values of the choice variables as functions of these parameters.

We noted that the shadow price of quality was an increasing function of the number of children. It would be tempting, therefore, to expect that an incomecompensated increase in the fixed cost per child - which unambiguously decreases the number of children - also would induce an increase in the demand for child quality through a lower shadow price of quality. This conclusion, however, is not warranted in quantity-quality models involving more than 2 goods, e.g., the 3-good model outlined above.' Although the signs of the cross-substitution effects between quantity and quality are ambiguous, the presence of non-linear budget constraints will make negative signs »less likely». A positive cross-substitution effect in the linear case is increased in magnitude by the quantity-quality interaction through the budget constraint. In fact, the cross-substitution effect in the non-linear case may be positive even if quality and quantity are complements in the linear case.

The Becker-Lewis approach to child quality is perhaps best viewed as relevant for parental investments in "younger» children. Investment decisions concerning older children, for example on higher education, may be regarded as taken by the children themselves, conditional on inherited »ability» and available financial and other resources. Ability, in turn, is determined by endowed genetic components as well as parental investments in child quality.

1 The comparative static properties of quantity-quality models have been investigated by Rosenzweig and Wolpin (1980) as well as Edlefsen (1981). 
Consider the following relations explaining the demand for quantity and quality of children,

$$
\begin{aligned}
& N=X \beta+\epsilon_{1} \\
& Q=X \lambda+\epsilon_{2}
\end{aligned}
$$

where $\mathrm{X}$ is a vector of variables capturing variations in prices and income and $\epsilon_{1}$ and $\epsilon_{2}$ are stochastic errors.

Parental investments in child quality will contribute to the children's intellectual development. Assume that the children's educational attainment (ED) is determined, in part, by »ability» as reflected in parental expenditures on child quality,

$$
\mathrm{ED}=\mathrm{Z} \theta+\tau_{1} \mathrm{~N}+\tau_{2} \mathrm{Q}+\epsilon_{3}
$$

where $\mathrm{Z}$ is a vector including variables affecting costs and returns to education. Note that the number of children enter as argument in (8) - in addition to quality. One important reason is that more children mean that less financial resources will be available for each child; schooling costs are likely to be an increasing function of the number of siblings.

\section{Empirical analysis}

\section{Variables and data}

The data analyzed are from the Swedish Level of Living Surveys of 1974 . We will explore the determinants of educational attainment among the respondents and the determinants of fertility among the respondents' parents. The sample was restricted to those (i) whose parents were Swedish citizens at date of birth, (ii) who had no serious health problem among family members during their childhood, and (iii) who were brought up in a family with both biological parents.

The three dependent variables of interest are number of children $(\mathrm{N})$, years of schooling (S) and level of education $\left(\mathrm{EL}_{\mathrm{j}}, \mathrm{j}=1, \ldots, 7\right)$. The assumption is that years of schooling and educational level have partly separate affects on wage rates. For example, a higher level of education at a given number of years of schooling will on average yield a higher return to market work.

The educational levels are represented by a number of dummy variables:

$\mathrm{EL}_{1}=$ basic compulsory six or seven year education (folkskola)

$\mathrm{EL}_{2}=$ vocational education for at least one year in addition to $\mathrm{EL}_{1}$

$\mathrm{EL}_{3}=$ junior high school (realexamen, grundskola, högre folkskola, flickskola, folkhögskola)

$\mathrm{EL}_{4}=$ vocational education for at least one year in addition to $\mathrm{EL}_{3}$

$\mathrm{EL}_{5}=$ high school (studentexamen)

$\mathrm{EL}_{6}=$ vocational education for at least one year in addition to $\mathrm{EL}_{5}$

$\mathrm{EL}_{7}=$ university degree.

A conceivable procedure is to estimate separate equations for years of schooling and level of education. We have adhered to a simpler approach and formed a new composite variable for educational level. This is derived from an estimated earnings function, which makes the natural logarithm of the wage rate a function of, inter alia, years of schooling, level of education, years of work experience and work experience squared, i.e.,

$$
\text { ln } \mathrm{W}_{\mathrm{i}}=\alpha_{0}+\alpha_{1} \mathrm{~S}_{\mathrm{i}}+\sum_{\mathrm{j}=2}^{7} \alpha_{\mathrm{j}} \mathrm{EL}_{\mathrm{ij}}+\alpha_{8} \mathrm{EXP}_{\mathrm{i}}+\alpha_{9} \mathrm{EXPSQ}_{\mathrm{i}}+\mathrm{u}_{\mathrm{i}}
$$

where $\mathrm{W}_{\mathrm{i}}$ is the ith individual's wage rate, $\mathrm{S}_{\mathrm{i}}$ is years of schooling, $\mathrm{EL}_{\mathrm{ij}}$ is educational level $\mathrm{j}, \mathrm{EXP}_{\mathrm{i}}$ is years of work experience, EXPSQ $\mathrm{i}_{\mathrm{i}}$ is work experience squared and $u_{i}$ is a stochastic error. 
The estimated wage equation can be used to compute the expected wage at labor market entry for each individual. This is given as

$$
\ln \hat{\mathrm{W}}_{0 \mathrm{i}}=\hat{\alpha}_{0}+\hat{\alpha}_{1} \mathrm{~S}_{\mathrm{i}}+\sum_{\mathrm{j}=2}^{7} \hat{\alpha}_{\mathrm{j}} \mathrm{EL}_{\mathrm{ij}}
$$

Turning next to the exogeneous variables affecting fertility and educational attainment, we have used age (a cohort variable), sex and dummies for father's education, mother's education, father's occupation and type of location. The reference group has six or seven years of education. The other education levels are as follows:

(i) education level 1 - vocational school;

(ii) education level $2-$ junior high school (realskola);

(iii) education level 3 - high school or higher education.

As is seen, information on parents' education is less detailed than information on education among the children.

Type of locality measures the degree of urbanization of the place in which the individual grew up (countryside, small community, small town, moderately large town, or large city). The type of locality variables are related to fixed costs per child for several reasons. First, food and housing have been cheaper in the countryside, (presumably also for non-farmers). Secondly, most likely there have been substantial differences in contraceptive costs between different type of localities. With increasing accessibility of inexpensive contraceptive technology, the net cost of having an extra child has increased. The hypothesis is that the net cost of contraceptives has been lower in big cities than in the countryside.

Type of locality may also be a candidate variable in the Z-vector, thereby having an effect on educational attainment independent of its effect on parental investment in quantity and quality of children. Variations in costs of education are to a large extent related to the accessibility of education within a given distance. Educational investments will seldom require simultaneous migration decisions for persons in big cities - but quite often so for individuals in the countryside. The latter are thereby facing higher pecuniary as well as psychic costs of education.

The parents' education and father's occupation capture the family's economic resources (full income). Education is also a proxy for the value of time, which is of crucial importance for time use and fertility decisions. For example, women with higher education are likely to spend more time in the labor market at the expense of timeintensive child care activities.

\section{Estimation}

Table 1 shows the estimated earnings function. In addition to education and work experience we have included controls for marital status, sex and living in a big city. An important issue is whether the various family background characteristics have effects on wage rates in addition to their effects on education. We tried to detect such influences by including parents' education, father's occupation, etc., in the wage equation. In almost all cases the estimated coefficients for background characteristics were insignificant and small. Our tentative conclusion, therefore, is that family background effects on earnings inequality are transmitted primarily through educational achievment. ${ }^{2}$

The estimated educational coefficients are used to predict wage rates at labor market entry according to Eq. (10). However, we run separate regressions for the

2 Blomquist (1979) has estimated an earnings function including several family background characteristics as regressors in addition to schooling, educational levels and work experience. Using a somewhat different sample and specification than ours he finds some significant direct family background effects on wage rates. 
T a b l e 1. The estimated earnings function. Dependent variable: $\ell$ n (1974 wage). (t-ratios in parentheses.)

\begin{tabular}{|c|c|c|c|}
\hline & t & (1) & (2) \\
\hline & Constant & $\begin{array}{c}6.995 \\
(164.4)\end{array}$ & $\begin{array}{c}7.004 \\
(156.3)\end{array}$ \\
\hline & Married & $\begin{array}{c}0.039 \\
(2.505)\end{array}$ & $\begin{array}{c}0.039 \\
(2.504)\end{array}$ \\
\hline & Woman & $\begin{array}{l}-0.199 \\
(-14.65)\end{array}$ & $\begin{array}{c}-0.199 \\
(-14.56)\end{array}$ \\
\hline & Big city & $\begin{array}{c}0.052 \\
(3.585)\end{array}$ & $\begin{array}{c}0.051 \\
(3.522)\end{array}$ \\
\hline & Experience & $\begin{array}{c}0.024 \\
(12.73)\end{array}$ & $\begin{array}{c}0.024 \\
(12.72)\end{array}$ \\
\hline & $(\text { Experience) })^{2} / 1000$ & $\begin{array}{l}-0.397 \\
(-10.51)\end{array}$ & $\begin{array}{l}-0.396 \\
(-10.46)\end{array}$ \\
\hline & Schooling & $\begin{array}{c}0.023 \\
(4.882)\end{array}$ & $\begin{array}{c}0.022 \\
(4.821)\end{array}$ \\
\hline & $\mathrm{EL}_{2}$ & $\begin{array}{c}0.074 \\
(3.239)\end{array}$ & $\begin{array}{c}0.074 \\
(3.211)\end{array}$ \\
\hline & $\mathrm{EL}_{3}$ & $\begin{array}{c}0.055 \\
(2.027)\end{array}$ & $\begin{array}{c}0.053 \\
(1.945)\end{array}$ \\
\hline & $\mathrm{EL}_{+}$ & $\begin{array}{c}0.115 \\
(3.950)\end{array}$ & $\begin{array}{c}0.114 \\
(3.900)\end{array}$ \\
\hline & $\mathrm{EL}_{5}$ & $\begin{array}{c}0.169 \\
(4.026)\end{array}$ & $\begin{array}{c}0.167 \\
(3.968)\end{array}$ \\
\hline & $\mathrm{EL}_{6}$ & $\begin{array}{c}0.225 \\
(4.854)\end{array}$ & $\begin{array}{c}0.224 \\
(4.825)\end{array}$ \\
\hline & $\mathrm{EL}_{7}$ & $\begin{array}{c}0.359 \\
(6.576)\end{array}$ & $\begin{array}{c}0.359 \\
(6.572)\end{array}$ \\
\hline & Number of children & - & $\begin{array}{l}-0.002 \\
(-0.663)\end{array}$ \\
\hline & $\mathrm{R}^{2}$ & 0.379 & 0.379 \\
\hline & Sample size & 1719 & 1719 \\
\hline
\end{tabular}

Note: The sample includes workers reported as employed in the Level of Living Survey of 1974 and who participated also in the 1968-survey (irrespective of labor force status in 1968). The wage rate is earnings per hour in Swedish Öre.

"year-variable» $\left(\hat{\alpha}_{1} S\right)$ and the »level-variable» $\left(\sum \hat{\alpha}_{j} E L_{j}\right)$. The analysis is here restricted to individuals who are at least 30 years old in order to avoid problems with a censored dependent variable; in other words, we prefer a sample that essentially includes those who have completed their basic formal education. The results are displayed in Table 2. Male-female differences in educational achievments are controlled for by an intercept dummy.

Of primary interest is the coefficient for the number of children. There is no obvious choice of functional form; it turned out that a logarithmic term produced a somewhat better fit than a linear function, which might reflect economies of scale in child care. As is seen, the fertility variable is highly significant and with the expected negative sign. It appears as if children's educational attainment is decreasing, at a decreasing rate, with the number of siblings in the family. The partial wage effect at $\mathrm{N}=2$ is one percent. Table 3 gives a more detailed picture of the implications of the estimates. It turns out that individuals from five children 
T a b l e 2. The determinants of educational attainment, (»quasi-reduced form») (t-ratios in parentheses.)

\begin{tabular}{|c|c|c|c|c|}
\hline 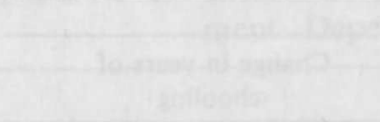 & $\begin{array}{l}\text { Equation for } \\
\text { years of } \\
\text { schooling }\end{array}$ & $\begin{array}{c}\text { Level of } \\
\text { education }\end{array}$ & $\begin{array}{l}\text { Total } \\
\text { effect }\end{array}$ & $\begin{array}{l}\text { Change } \\
\text { in years } \\
\text { of schooling }\end{array}$ \\
\hline & $\begin{array}{l}\left(\hat{\alpha}_{1} S\right) \\
(1)\end{array}$ & $\begin{array}{c}\left(\sum \hat{\alpha}_{j} E L_{j}\right) \\
(2)\end{array}$ & $\begin{array}{c}(1)+(2) \\
(3)\end{array}$ & (4) \\
\hline Constant & $\begin{array}{c}0.256 \\
(47.46)\end{array}$ & $\begin{array}{c}0.110 \\
(16.63)\end{array}$ & & \\
\hline 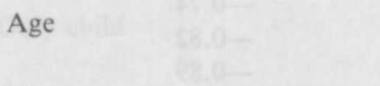 & $\begin{array}{l}-0.001 \\
(-15.55)\end{array}$ & $\begin{array}{l}-0.001 \\
(-11.19)\end{array}$ & -0.002 & -0.062 \\
\hline $\cos 200=$ & $\begin{array}{l}-0.008 \\
(-3.747)\end{array}$ & $\begin{array}{l}-0.014 \\
(-5.083)\end{array}$ & -0.022 & -0.374 \\
\hline ln (Number of children) & $\begin{array}{l}-0.010 \\
(-5.363)\end{array}$ & $\begin{array}{l}-0.011 \\
(-4.752)\end{array}$ & -0.021 & -0.459 \\
\hline \multicolumn{5}{|l|}{ Parents' education: } \\
\hline Educ. level 1 , father & $\begin{array}{c}0.020 \\
(4.310)\end{array}$ & $\begin{array}{c}0.022 \\
(3.814)\end{array}$ & 0.042 & 0.895 \\
\hline Educ. level 2, father & $\begin{array}{c}0.042 \\
(7.429)\end{array}$ & $\begin{array}{c}0.052 \\
(7.492)\end{array}$ & 0.094 & 1.850 \\
\hline Educ. level 3, father & $\begin{array}{c}0.042 \\
(5.416)\end{array}$ & $\begin{array}{c}0.047 \\
(4.945)\end{array}$ & 0.089 & 1.869 \\
\hline Educ. level 1 , mother & $\begin{array}{c}0.017 \\
(2.539)\end{array}$ & $\begin{array}{c}0.018 \\
(2.152)\end{array}$ & 0.035 & 0.768 \\
\hline Educ. level 2, mother & $\begin{array}{c}0.050 \\
(8.537)\end{array}$ & $\begin{array}{c}0.054 \\
(7.537)\end{array}$ & 0.104 & 2.204 \\
\hline Educ. level 3, mother & $\begin{array}{c}0.062 \\
(6.393)\end{array}$ & $\begin{array}{c}0.078 \\
(6.494)\end{array}$ & 0.140 & 2.769 \\
\hline \multicolumn{5}{|l|}{ Father's occupation: } \\
\hline Unskilled blue-collar worker & $\begin{array}{l}-0.004 \\
(-1.194)\end{array}$ & $\begin{array}{l}-0.007 \\
(-1.536)\end{array}$ & -0.011 & -0.191 \\
\hline Skilled blue-collar worker & $\begin{array}{c}0.005 \\
(1.466)\end{array}$ & $\begin{array}{c}0.002 \\
(1.399)\end{array}$ & 0.007 & 0.232 \\
\hline $\begin{array}{l}\text { Lower level white- } \\
\text { collar worker }\end{array}$ & $\begin{array}{l}0.025 \\
(5.680)\end{array}$ & $\begin{array}{c}0.025 \\
(4.505)\end{array}$ & 0.050 & 1.128 \\
\hline $\begin{array}{l}\text { Upper level white- } \\
\text { collar worker }\end{array}$ & $\begin{array}{c}0.049 \\
(5.616)\end{array}$ & $\begin{array}{c}0.064 \\
(5.192)\end{array}$ & 0.113 & 2.197 \\
\hline $\begin{array}{l}\text { Self-employed, } \\
\text { no employees }\end{array}$ & $\begin{array}{c}0.001 \\
(0.151)\end{array}$ & $\begin{array}{l}-0.006 \\
(-0.870)\end{array}$ & -0.005 & 0.037 \\
\hline $\begin{array}{l}\text { Self-employed, } \\
\text { with employees }\end{array}$ & $\begin{array}{c}0.035 \\
(7.058)\end{array}$ & $\begin{array}{c}0.031 \\
(5.109)\end{array}$ & 0.066 & 1.536 \\
\hline \multicolumn{5}{|l|}{$\begin{array}{l}\text { Type of locality } \\
\text { during childhood: }\end{array}$} \\
\hline Small community & $\begin{array}{c}0.005 \\
(1.658)\end{array}$ & $\begin{array}{c}0.007 \\
(1.817)\end{array}$ & 0.012 & 0.242 \\
\hline Small town & $\begin{array}{c}0.004 \\
(0.774)\end{array}$ & $\begin{array}{c}0.003 \\
(0.463)\end{array}$ & 0.007 & 0.178 \\
\hline Middle sized town & $\begin{array}{l}0.025 \\
(6.495)\end{array}$ & $\begin{array}{c}0.019 \\
(4.063)\end{array}$ & 0.044 & 1.124 \\
\hline Big city & $\begin{array}{c}0.025 \\
(5.515)\end{array}$ & $\begin{array}{l}0.016 \\
(2.864)\end{array}$ & 0.041 & 1.090 \\
\hline $\mathrm{R}^{2}$ & 0.423 & 0.348 & & \\
\hline Sample size & 2425 & 2425 & & \\
\hline
\end{tabular}

Note: The reference groups are: parents' education - compulsory six- or seven-year school (folkskola): father's occupation - farmer or blue-collar worker with small farm: type of locality - countryside. 
T a b l e 3. Fertility and children's education.

\begin{tabular}{ccc}
\hline Number of children & $\begin{array}{c}\text { Change in } \text { ?n entry } \\
\text { wage rate }\end{array}$ & $\begin{array}{c}\text { Change in years of } \\
\text { schooling }\end{array}$ \\
\hline 1 & 0 & 0 \\
2 & -0.015 & -0.32 \\
3 & -0.023 & -0.50 \\
4 & -0.029 & -0.64 \\
5 & -0.034 & -0.74 \\
6 & -0.038 & -0.82 \\
7 & -0.041 & -0.89 \\
8 & -0.044 & -0.95 \\
9 & -0.046 & -1.01 \\
10 & -0.048 & -1.06 \\
\hline
\end{tabular}

families receive 2 percent lower entry wages than persons from two-children families.

Among other results, it can be noted that children's education is strongly influenced by parents' education and father's occupation. The estimates imply, for example, that children of more highly educated parents (education level 3) and with a father in an upper level white collar occupation, receive 37 percent higher wage rates than children from an unskilled blue-collar worker family where the parents only have six or seven years of schooling.

\section{Other issues: Birth order and spacing}

An inverse correlation between birth order and the children's mental achievment shows up in many psychological studies. An interpretation in terms of life cycle changes in the production of child quality is conceivable and has been put forward by, e.g., Razin (1980). The basic idea is that the well-being of a child is closely related to the amount of time allocated to it by its parents. The lower the birth order of a child, the longer he or she receives benefits from child rearing.

The birth order issue is related to the question of spacing of children. If child quality is an increasing function of parental time in child care, we would expect that longer birth intervals will improve child quality. We have used one variable to explore this possibility, the distance (in years) to the closest sibling.

Table 4 displays results of testing for effects of several variables capturing sibling position. Birth order as well as only child have coefficients with negative signs but they are always close to zero and far from significant. Interestingly, the spacing variable has a significant positive coefficient, holding total number of children constant. Siblings born six years apart appear to receive a schooling advantage that corresponds to a wage premium of 2 percent, compared to siblings born only one year apart. The coefficient for the number of children increases somewhat (in absolute value) when the spacing variable is included.

The data set contains some information on labor force behavior among the respondents' mothers. We appended two dummies to the equation for (total) educational attainment representing (i) market work during most years of the respondent's childhood, or (ii) market work during shorter periods. The first variable had a positive coefficient with a t-ratio at 2.0 , whereas the second variable had a negative but insignificant coefficient. The fertility coefficient remained basically unchanged when the labor force participation variables were included.

\section{Concluding remarks}

This study is an attempt to quantify the relationship between family size and children's educational acievement in Sweden, using the economic quantity-quality 
$\mathrm{T}$ a b l e 4. Effects of birth order and spacing on children's educational attainment. Dependent variable: $\mathrm{n}$ wage rate at labor market entry.

\begin{tabular}{lccccc}
\hline & $(1)$ & $(2)$ & $(3)$ & $(4)$ & $(5)$ \\
\hline $\begin{array}{l}\text { In (Number } \\
\text { of children) }\end{array}$ & -0.021 & -0.024 & -0.023 & -0.028 & -0.027 \\
Birth order & $(-4.004)$ & $(-4.494)$ & $(-3.456)$ & $(-5.025)$ & $(-2.944)$ \\
& -0.00034 & & -0.00010 & & -0.00012 \\
Only child & $(-0.220)$ & & $(-0.065)$ & & $(-0.074)$ \\
& & -0.0066 & -0.0064 & -0.0079 & -0.0077 \\
$\begin{array}{l}\text { Distance to } \\
\text { closest sibling (years) }\end{array}$ & & $(-0.602)$ & $(-0.564)$ & $(-0.726)$ & $(-0.681)$ \\
\hline
\end{tabular}

Note: Additional regressors are those given in Table 2 above.

approach to fertility as a guide for the empirical analysis. Other theoretical approaches are, of course, conceivable, including those with less emphasis on purposeful actions on part of the parents. A larger family size is likely to involve a strain on parents' resources irrespective of whether they actually plan for a utility maximizing quantity-quality trade-off.

The empirical analysis does indeed reveal that a greater number of siblings reduces the schooling level for each child. The estimated coefficients are »small» but highly significant. In fact, the coefficients are fairly close to estimates produced on U.S. data sets. We also provided some support for the "spacing hypothesis», it appears as if longer birth intervals lead to higher educational attainment among the children. Contrary to several other studies, we found no support for the idea that family size effects primarily capture the importance of birth order.

Our analysis has focused on the children's educational attainment and ignored other welfare measures. Although higher education is associated with higher wage rates, it is likely that family background characteristics - including family size will be less important for the dispersion in lifetime earnings than for the dispersion in wages at a point in time. For example, persons with higher education will spend fewer years in the labor force. On the other hand, there are presumably also various non-pecuniary benefits from investments in education which will strengthen the basic »cost of sibling» hypothesis.

\section{References}

Becker, G. S. (1981). A treatise on the family. Harvard University, Cambridge, Massachusetts.

- and Lewis, H. G. (1973). On the interaction between the quantity and quality of children. Journal of Political Economy, 81: 279-288.

Blomquist, N. S. (1979). Wage rates and personal characteristics. Scandinavian Journal of Economics 81: $505-520$.

Edlefsen, L. E. (1981). The comparative statics of hodonic price functions and other nonlinear constraints. Econometrica 49: 1501-1520.

Razin, A. (1980). Number, spacing and quality of children: a microeconomic viewpoint. In: Research in population economics 2, edited by J. L. Simon and J. DaVanzo. JAI Press, Greenwich, Connecticut.

Rosenzweig, M. R. and Wolpin, K. I. (1980). Testing the quantity-quality fertility model: the use of twins as a natural experiment. Econometrica 48: 227-240.

Walldén, M. (1982). Sibling position and mental capacity. Research Report No. 20, Project Metropolitan. University of Stockholm, Department of Sociology. 